\title{
Solução Supersaturada
}

\author{
Maria Domitila de Menezes * \\ amoita@mail.telepac.pt \\ Escola Superior de Educação de Lisboa - Portugal \\ Maria João M. Curto * \\ INETI - Portugal
}

Informações do Artigo

Histórico do Artigo

Criado em Novembro de 1998
Resumo

O experimento descrito, voltado aos alunos do nível médio, visa explorar conceitos de físico-química observando o comportamento de uma solução supersaturada de acetato de sódio.

\section{Palavras-Chaves \\ Solução \\ Solução supersaturada \\ Cristalização \\ Reação exotérmica}

Ensino

\section{Objetivo}

Observar o comportamento de soluções supersaturadas

\section{\Atenção: \\ Ler o procedimento com muita atenção, antes de começar a experiência.}

Não realizar o experimento sem o acompanhamento do seu professor. Peça ajuda em caso de dúvida.

\section{Materiais e reagentes necessários}

- Acetato de sódio

- Água destilada

- Erlenmeyer de $200 \mathrm{~mL}$

- Vidro de relógio e vareta

- Placa de aquecimento

Segurança

- Manusear o material quente com precaução.

- Ter cuidado com a placa de aquecimento.

- Não utilize forno de microondas para aquecimento.

- Observar os outros itens de segurança (Pesquisar nos artigos presentes neste site). 


\section{Procedimento}

1. Pesar $50 \mathrm{~g}$ de acetato de sódio no erlenmeyer depois de previamente tarado.

2. Dissolver o acetato de sódio em $5,0 \mathrm{~mL}$ de água destilada, aquecendo até que se dissolva completamente.

3. Deixar esfriar, em repouso, a solução obtida ( pode ser necessário preparar esta solução supersaturada, de véspera)

4. Colocar um cristal de acetato de sódio no vidro de relógio.

5. Pingar sobre o cristal, gota a gota, a solução supersaturada de acetato de sódio, que deve estar à temperatura ambiente.

6. Observar e verificar a alteração de temperatura colocando a mão debaixo do vidro de relógio.

O que aconteceu?

- Acabou-se de observar uma cristalização exotérmica, a partir de uma solução supersaturada de acetato de sódio.

- Quando se adiciona um cristal de um sal a uma solução supersaturada desse sal, ocorre a sua cristalização.

- A dissolução de um sólido iônico em água é em geral, mas nem sempre, acompanhada por uma variação de temperatura.

- Este fenômeno deve-se a que, no processo de dissolução, é absorvida energia necessária para quebrar as ligações iônicas na rede cristalina do sólido iônico e simultaneamente é liberada energia, quando os íons livres se ligam às moléculas de água, para ficarem hidratados.

A cristalização do acetato de sódio é um processo altamente exotérmico, que encontra aplicação em compressas instantâneas quentes, constituídas por um saco de plástico selado contendo uma solução saturada de acetato de sódio em água e um pequeno disco metálico [Figura 1]. Comprimindo-se o disco metálico, provocase a cristalização do acetato de sódio com conseqüente evolução de calor. Estas compressas são reutilizáveis e para que o sólido cristalizado se dissolva de novo é necessário aquecer o saco contendo o acetato de sódio cristalizado em água fervente.

Usualmente o processo de cristalização necessita de uma semente de cristalização ou de algum tipo de efeito perturbador que forneça energia suficiente para que a cristalização tenha início. Neste experimento em particular, o disco metálico servirá apenas como agente iniciador da cristalização. Ao ser deformado, proporciona-se o mínimo de energia necessário para o início da precipitação. É possível ainda que a deformação do disco produza defeitos em sua superfície, que possibilitarão a formação dos primeiros cristais, servindo como semente da cristalização. Uma vez que está sendo usado um disco metálico como iniciador da precipitação, o reaproveitamento da compressa NÃO deve ser feito por aquecimento em forno de microondas.

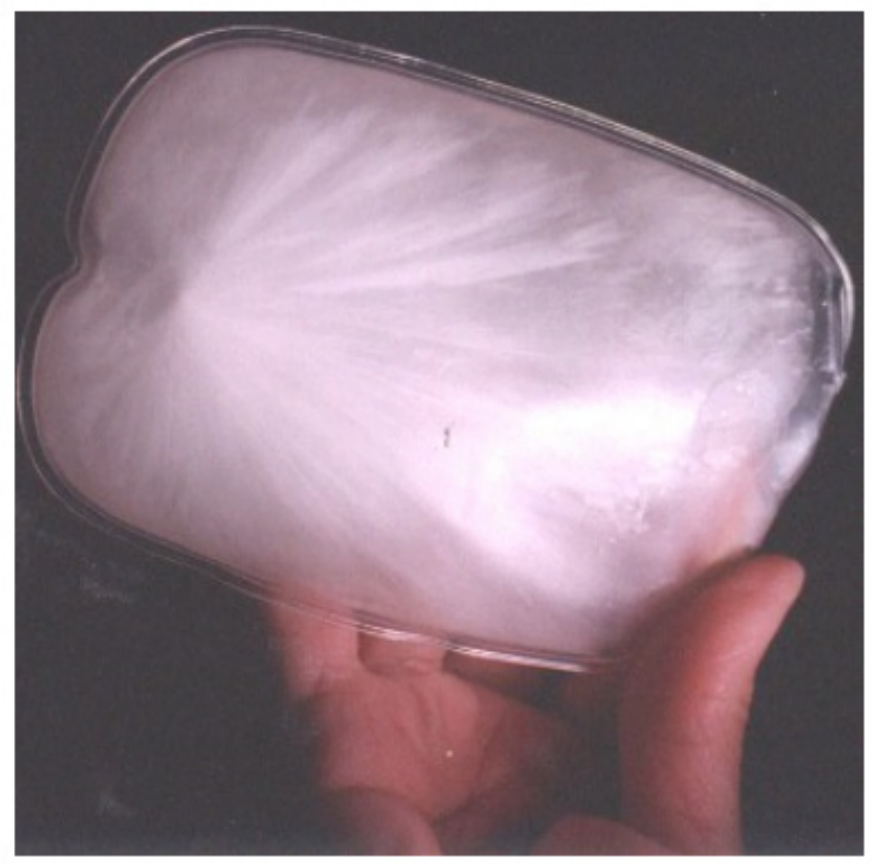

Figura 1 - Compressa instantânea com o acetato de sódio já cristalizado. 